\title{
A joint data record of tropospheric ozone from Aura-TES and MetOp-IASI
}

\author{
Hilke Oetjen ${ }^{1,2}$, Vivienne H. Payne ${ }^{1}$, Jessica L. Neu ${ }^{1}$, Susan S. Kulawik ${ }^{1,3}$, David P. Edwards ${ }^{4}$, Annmarie Eldering ${ }^{1,2}$, \\ Helen M. Worden ${ }^{4}$, and John R. Worden ${ }^{1}$ \\ ${ }^{1}$ Jet Propulsion Laboratory, California Institute of Technology, Pasadena, California, USA \\ ${ }^{2}$ The UCLA/JPL Joint Institute for Regional Earth System Science and Engineering, Los Angeles, California, USA \\ ${ }^{3}$ BAER Institute, Mountain View, California, USA \\ ${ }^{4}$ National Center for Atmospheric Research, Boulder, Colorado, USA \\ Correspondence to: Vivienne H. Payne (vivienne.h.payne@jpl.nasa.gov)
}

Received: 17 September 2015 - Published in Atmos. Chem. Phys. Discuss.: 6 November 2015

Revised: 13 July 2016 - Accepted: 13 July 2016 - Published: 12 August 2016

\begin{abstract}
The Tropospheric Emission Spectrometer (TES) on Aura and Infrared Atmospheric Sounding Interferometer (IASI) on MetOp-A together provide a time series of 10 years of free-tropospheric ozone with an overlap of 3 years. We characterise the differences between TES and IASI ozone measurements and find that IASI's coarser vertical sensitivity leads to a small $(<5 \mathrm{ppb})$ low bias relative to TES for the free troposphere. The TES-IASI differences are not dependent on season or any other factor and hence the measurements from the two instruments can be merged, after correcting for the offset, in order to study decadal-scale changes in tropospheric ozone. We calculate time series of regional monthly mean ozone in the free troposphere over eastern Asia, the western United States (US), and Europe, carefully accounting for differences in spatial sampling between the instruments. We show that free-tropospheric ozone over Europe and the western US has remained relatively constant over the past decade but that, contrary to expectations, ozone over Asia in recent years does not continue the rapid rate of increase observed from 2004 to 2010.
\end{abstract}

\section{Introduction}

Tropospheric ozone adversely impacts human health and ecosystems at the Earth's surface and plays a key role in photochemistry throughout the troposphere. Ozone also acts as a greenhouse gas in the upper troposphere (e.g. Gauss et al., 2003; Worden et al., 2008; Bowman and Henze,
2012). Sources of tropospheric ozone include photochemical production from non-methane volatile organic compounds (NMVOCs) and carbon monoxide (CO) in the presence of nitrogen oxide radicals $\left(\mathrm{NO}_{x}\right)$ as well as transport from the stratosphere into the troposphere (e.g. Worden et al., 2009; Young et al., 2013; Neu et al., 2014).

The lifetime of ozone in the free troposphere is on the order of several weeks (e.g. Stevenson et al., 2006). Hence, regional changes in ozone precursor emissions or in transport can have implications for tropospheric ozone concentrations on a global scale. In recent years, rapid urbanisation and industrialisation in China have led to large changes in ozone precursor emissions. Measurements over Asia have shown ozone increasing in the decade leading up to 2010 (e.g. Tanimoto et al., 2009; Wang et al., 2012; Lee et al., 2014). Increases in $\mathrm{NO}_{x}$ (for $\mathrm{NO}_{2}$, see, e.g., van der $\mathrm{A}$ et al., 2008; Hilboll et al., 2013) and NMVOCs (for formaldehyde, see De Smedt et al., 2009) - as well as tropospheric ozone (Beig and Singh, 2007) - have been observed from space, although $\mathrm{CO}$ has been shown to be decreasing over China (Worden et al., 2013).

Emissions from China dominate the Asian pollutant outflow (e.g. Zhang et al., 2009). Several studies report transPacific transport of pollution plumes (e.g. Zhang et al., 2008; Singh et al., 2009). With increasing Asian pollution, an enhancement of ozone concentrations in the western US is expected (Jiang et al., 2015). Several model studies (e.g. Jacob et al., 1999; Wild and Akimoto, 2001; Fiore et al., 2009; Reidmiller et al., 2009; Lin et al., 2012; Fry et al., 2013, 
2014) evaluated the intercontinental impact of ozone precursors emissions in midlatitude industrial areas on the ozone concentrations in downwind regions. Increases in Asian pollution have previously been assumed to be associated with positive trends in ozone in the western US (Jaffe and Ray, 2007; Parrish et al., 2009; Cooper et al., 2010; Verstraeten et al., 2015).

Pollutant trends for Europe and northern America do not provide such a consistent picture. Ebojie et al. (2016) have found negative albeit not significant trends of tropospheric ozone columns over the western US analysing SCIAMACHY (SCanning Imaging Absorption SpectroMeter for Atmospheric CHartographY) measurements for the period of 2003 to 2011. On the other hand, parts of Europe show a significant negative trend in the SCIAMACHY data (Ebojie et al., 2016). Cooper et al. (2014) compiled ground-based surface ozone measurements and lowermost-tropospheric measurements from aircraft and ozone sondes and calculated trends beginning 1990-1999 through 2000-2010 and found mostly positive trends for the western US and negative ones for the eastern US. Europe showed a positive ozone trend in this data set. However, as pointed out by Cooper et al. (2014), European ground-based measurements do not show a positive trend from about 2000 onwards. $\mathrm{NO}_{2}$ tropospheric columns have been reported to decrease over North America and Europe (e.g. Hillboll et al., 2013).

The Tropospheric Emission Spectrometer (TES), launched on board the Aura satellite in 2004, was specifically designed to measure tropospheric ozone by means of fine spectral resolution $\left(0.1 \mathrm{~cm}^{-1}\right)$ radiance measurements in the thermal infrared. However, the near-global TES record of tropospheric ozone ended in 2011 when the TES observing strategy shifted away from routine global survey measurements in order to focus on special observations over select regions, to preserve the lifetime of the instrument. The Infrared Atmospheric Sounding Instrument (IASI), flying on the MetOp satellites since the launch of MetOp-A in 2006 and continuing with MetOp-B in 2012, is designed for both atmospheric composition and numerical weather prediction applications (Clerbaux et al. 2009). Although the spectral resolution of the IASI measurements, at $0.5 \mathrm{~cm}^{-1}$, is coarser than TES, IASI retrievals have been shown to provide a wealth of useful information on tropospheric ozone (e.g. Dufour et al., 2010; Safieddine et al., 2013; Oetjen et al., 2014). The IASI instruments offer the dual advantages of extensive spatial coverage and a record that is assured to continue well into the future with the launch of the MetOp-C platform in 2018. Here we show that TES and IASI ozone measurements can be combined and used to investigate changes in tropospheric ozone over the past decade, with a focus on eastern Asia, the western US, and Europe.

\section{Satellite measurements of tropospheric ozone from TES and IASI: observations and retrieval approach}

IASI-1 flies in a sun-synchronous orbit on MetOp-A. The local overpass times at the equator are 09:30 and 21:30 LT. IASI is a scanning instrument and achieves global coverage twice daily. At nadir, the footprint is a circle with $12 \mathrm{~km}$ diameter, while on the sides of the swath the footprint is elongated elliptically to $20 \mathrm{~km} \times 39 \mathrm{~km}$. TES on the AURA satellite, on the other hand, measures in the nadir only, with a rectangular surface footprint of $5.3 \mathrm{~km} \times 8.3 \mathrm{~km}$. TES orbits are separated by $22^{\circ}$ longitude, and in the nominal observation mode (which is used in this study and called global survey), measurements are taken every $182 \mathrm{~km}$ along the flight track. The equator crossing times are 01:45 and 13:45 LT. TES has a spectral resolution of $0.1 \mathrm{~cm}^{-1}$ full-width half maximum (FWHM) and a spectral sampling of $0.06 \mathrm{~cm}^{-1}$. IASI measures with a coarser resolution of $0.5 \mathrm{~cm}^{-1}$ FWHM and a sampling of $0.25 \mathrm{~cm}^{-1}$, resulting in slightly less vertical information for the trace gas retrievals (Oetjen et al., 2014). The noise equivalent differential temperatures are $0.15 \mathrm{~K}$ at $280 \mathrm{~K}$ and $0.3 \mathrm{~K}$ at $300 \mathrm{~K}$ for IASI and TES, respectively. In this work, the TES optimal estimation retrieval algorithm (Bowman et al., 2002, 2006) has been applied to the IASI radiances in order to maintain consistency between the records in terms of a priori constraints and retrieval method. One difference we maintain is that for TES, temperature, clouds, and emissivity, all of which are important parameters for an accurate ozone retrieval, are also retrieved with the TES algorithm in steps before the actual ozone analysis. For IASI, we use the operational EUMETSAT level 2 data for temperature and clouds and we use the Zhou climatology for emissivity (Zhou et al., 2011). The TES ozone results shown here are from the v05 Level 2 Lite data (http://tes.jpl.nasa.gov/data/). Details for the retrievals can be found in Bowman et al. (2006), Kulawik et al. (2006), and Oetjen et al. (2014).

\section{Construction of a combined ozone record}

Combining TES and IASI measurements into a merged time series requires careful consideration of differences in sensitivity and sampling. No differences due to the retrieval settings are expected since the same algorithm, a priori profiles, and constraints have been applied to the radiances of the two instruments. In this section, we describe the methodology for comparing and homogenising the datasets.

\subsection{Characterisation of retrieval profile differences}

Estimates of tropospheric ozone based on IASI radiances and the TES optimal estimation algorithm (IASI-TOE) have been validated against sonde data in previous work; details of the prior constraints, retrieval levels, and spectral windows, as well as the predicted and actual errors and the biases with respect to the sondes, can be found in Oetjen et 
al. (2014). Biases of TES ozone with respect to ozonesondes are investigated in Verstraeten et al. (2013). Both instruments show a similar positive bias in the upper tropospherelower stratosphere in comparison to sondes. This bias is believed to originate from incorrect spectroscopic parameters (e.g. Oetjen et al., 2014). Here, we quantify differences between TES and IASI-TOE ozone in order to assess the feasibility of merging the time series of the two instruments. We select four TES global surveys (GSs) approximately 3 months apart (3-4 August 2008, 1-2 November 2008, 1718 February 2009, 26-27 May 2009; a GS takes about 26 h, and these were chosen since they had the highest number of successful retrievals in the corresponding months) and compare the ozone profiles and retrieval sensitivities with collocated IASI-TOE retrievals. The coincidence criteria are $55 \mathrm{~km}$ (corresponding to $0.5^{\circ}$ latitude) and $5 \mathrm{~h}$. The time difference, which is larger than typically used for defining coincident trace gas profiles, is driven by the different overpass times of the Aura and MetOp-A satellites. TES scenes with an average cloud optical depth of 0.1 or less and IASI scenes with a cloud fraction of $6 \%$ or less are included. Further, for TES, the data were filtered by the retrieval quality and the C-curve flags (see TES user guides, http://tes.jpl.nasa. gov/documents/), and IASI was limited to retrievals with a $\chi^{2}$ less than 1.3 (see Oetjen et al., 2014). Because of IASI's dense sampling, there can be multiple IASI co-locations for a TES scene. Overall, there are 3992 IASI measurements and 745 TES measurements for the four TES global surveys. Results of the TES-IASI comparison are shown in Fig. 1 for all GSs together. Panels $a$ and $b$ show the average profile of the sum of the rows of the averaging kernel (AK) matrices and of ozone along with their standard deviations, respectively. The TES sensitivity is slightly better than IASI throughout most of the atmosphere as expected due to the finer spectral resolution of TES compared to IASI. The differences in the sensitivity are likely the reason for the different ozone profile shapes for TES and IASI-TOE; while the mean IASI-TOE ozone follows the general shape of the a priori profile (although not its absolute values), the mean TES profile shape deviates from the a priori profile shape in the mid and upper troposphere. The large standard deviation on the ozone profile in the stratosphere results from the rather large latitudinal range that is covered by the measurements: $50^{\circ} \mathrm{S}-80^{\circ} \mathrm{N}$. This also includes some profiles affected by the ozone hole at high latitude. The relative differences are shown in panels $\mathrm{c}$ and d, plotted as the mean of the individual differences. On average, IASI ozone abundances are less than those from TES between the surface and $\sim 250 \mathrm{hPa}$, with a maximum difference of $-13 \%$ at $500 \mathrm{hPa}$. Above $250 \mathrm{hPa}$, IASI-TOE ozone is greater than TES ozone, with a maximum difference of $8 \%$ at about $150 \mathrm{hPa}$. Despite the fact that the ozone profiles themselves vary significantly with latitude and season owing to variations in tropopause altitude (Fig. 1b), the differences between IASI and TES ozone (Fig. 1d) are relatively consistent in shape and magnitude across seasons and latitudes, with the IASI-TES differences showing a standard deviation of only $\sim 20 \%$ in the upper troposphere for the whole dataset, compared to the extremely large standard deviations in the ozone upper tropospheric volume mixing ratio. Note that the differences between IASI-TOE and TES approach zero at the surface and towards the top at the atmosphere because the retrievals essentially return the a priori in these regions due to the low sensitivities. The IASI-TOE precision in the free troposphere was estimated to be better than $20 \%$ (Oetjen et al., 2014). TES precision in the free troposphere has previously been shown to be $10-15 \%$ (Boxe et al., 2010). Therefore, TES and IASI-TOE ozone profiles agree well within their respective uncertainties. Two examples for the individual GS overviews are given in the Supplement in Figs. S1 and S2 for August and November, respectively.

\subsection{Characterisation of differences for column-averaged mixing ratios}

In the following, we present results on column-average mixing ratios between 681 and $316 \mathrm{hPa}$, a range where both the TES and IASI-TOE ozone retrievals show good sensitivity. The degrees of freedom for signal for both TES and IASI for the considered altitude range are between 0.7 and 0.8. This range includes five retrieval vertical grid points, and the data are the same collocated data as in Sect. 3.1.

The differences between TES and IASI partial column mean mixing ratios as a function of the IASI-TOE sensitivity are shown in Fig. 2. The sum of the AK matrix in the relevant pressure range is used as a measure of the sensitivity. For this we calculate the sum of the rows of the AK matrix for each of the retrieval levels in the specified range and then add those together. The peak values of the TES AKs are larger than IASI's; however, the FWHM of the TES AKs is narrower. Since we are averaging ozone over a range of several retrieval levels, the total area under the AKs is more representative of the information content than just the sum of the peak values. The data points in Fig. 2 are colourcoded for the mean IASI-TOE ozone mixing ratio as indicated in the legend. Although the sensitivity of the ozone retrievals depends on the amount of ozone itself and although there is a wide range of the (IASI-TES) differences, these differences appear to be independent of the sensitivity and the actual ozone amount (see Fig. 2). Apart from instrument specifications, the sensitivity of infrared instruments towards ozone depends on the atmospheric and surface temperatures, water vapour amount, residual cloud contamination, surface emissivity, and the amount of ozone itself. The uncertainties in the IASI ozone profile have been estimated to be less than $2 \%$ from the water vapour uncertainty and less than $5 \%$ from the temperature profile (Oetjen et al., 2014). The uncertainty from the surface temperature is negligible. Collocated retrievals as considered here should all be affected in a similar way by these external parameters. However, the instrumental difference in the spectral resolution of TES and IASI 

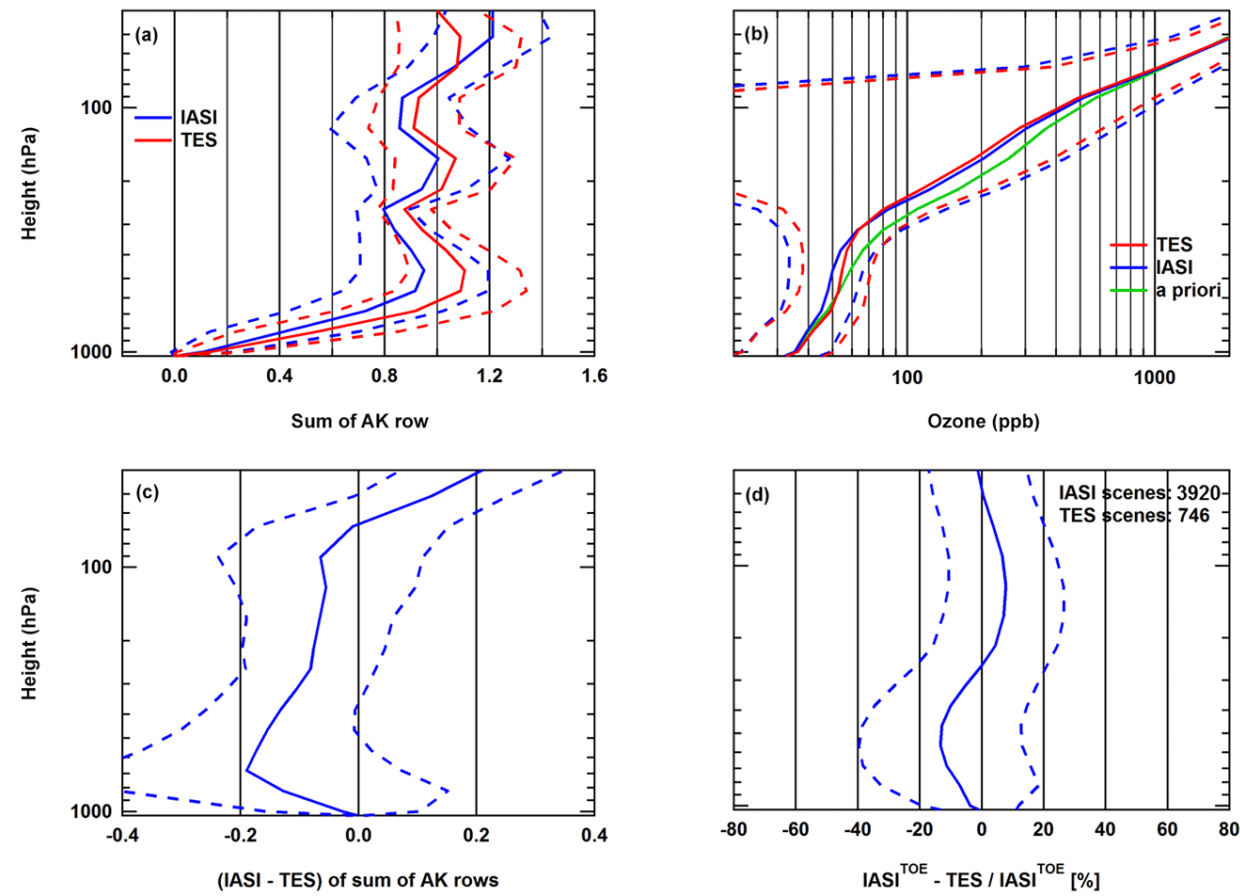

Figure 1. Ozone profiles (b) and vertical sensitivities (a) for TES and IASI-TOE, respectively. Also shown are the differences between TES and IASI $(\mathbf{c}, \mathbf{d})$. Solid lines are the mean values and dashed lines the standard deviations.

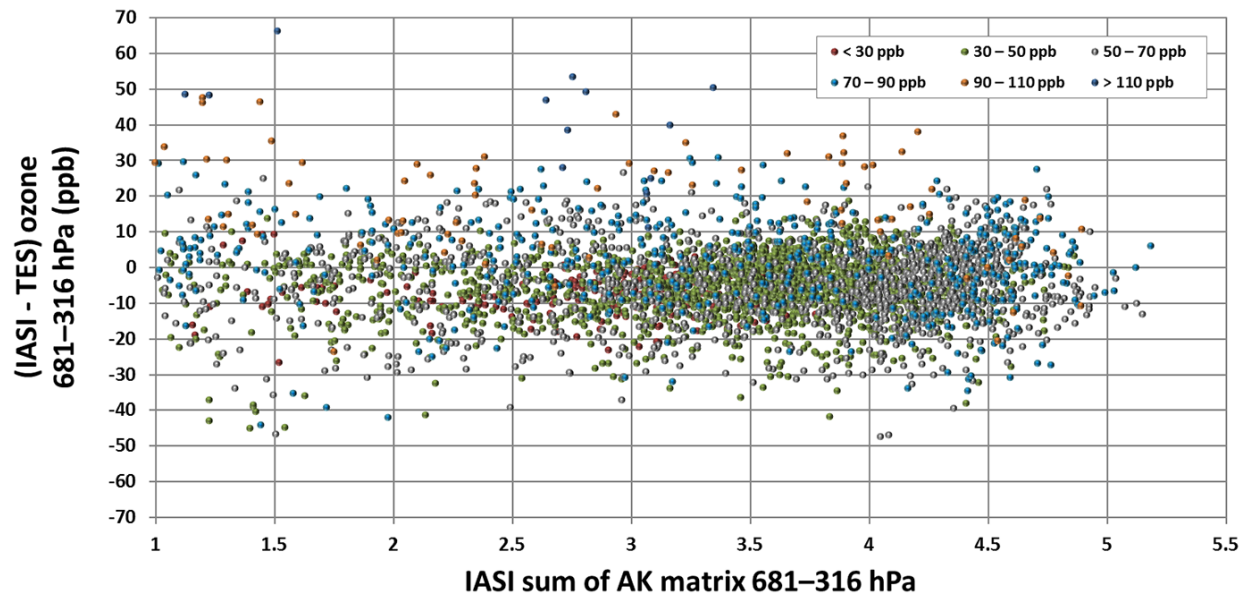

Figure 2. Differences between IASI-TOE and TES 681-316 hPa average ozone mixing ratio as a function of the sum of the IASI-TOE AK matrix in the same pressure range. The markers' colour represents IASI-TOE ozone mixing ratio bins as annotated in the legend. The offset between IASI-TOE and TES neither depends on the measurement sensitivity nor the ozone mixing ratio.

results in different weighting functions that give a simple offset between the ozone retrievals.

The normalised frequency distribution of the offset of the data of Fig. 2 is shown in Fig. 3. The distribution of the difference between TES and IASI-TOE follows roughly a Gaussian function with the maximum at $-3.9 \pm 0.2 \mathrm{ppb}$ (see Table 1, last row). For merging the TES and IASI-TOE data series, only the location of the peak value is important. The width of the frequency distribution, defined by the FWHM, is $17.6 \mathrm{ppb}$ and is determined by the precision of the measurements and the colocation error: the precision for the IASI-TOE retrieval was estimated to be better than $20 \%$ (see Sect 3.1). Those $20 \%$ were calculated from a comparison with ozone sondes with a coincidence criterion of also $55 \mathrm{~km}$ (Oetjen et al., 2014). Hence, a possible spatial colocation error is included in this estimate. This translates into $10.4 \mathrm{ppb}$ for a mean IASI-TOE ozone of $51.9 \mathrm{ppb}$ for the IASI precision plus spatial colocation. The TES precision 


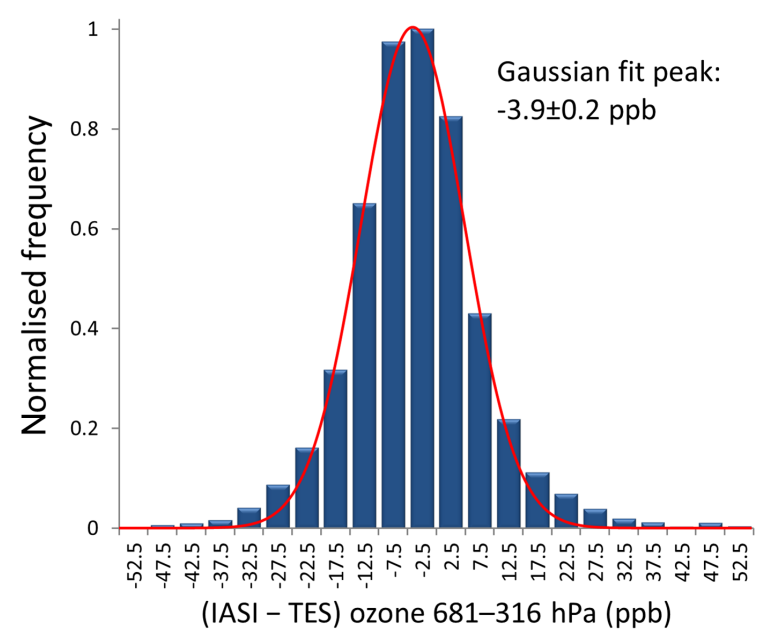

Figure 3. Normalised frequency distribution of the offset of the data of Fig. 2. The distribution of the difference between TES and IASI-TOE follows roughly a Gaussian function with the maximum at $(-3.9 \pm 0.2) \mathrm{ppb}$

of $15 \%$ translates into $8.3 \mathrm{ppb}$ for $55.4 \mathrm{ppb}$ mean ozone. To estimate the temporal colocation error, we compared model fields (GEOS-Chem version 10.1; Bey et al., 2001; Eastham et al., 2014) for the dates of the four global surveys for the overpass times of IASI and TES and calculated the standard deviation of the ozone difference, which is $1.7 \mathrm{ppb}$. Adding the IASI combined precision and spatial colocation estimate, the TES precision, and the temporal colocation estimate in quadrature gives $\sim 14 \mathrm{ppb}$, which is slightly smaller than but not dramatically different from the FWHM in Fig. 3.

Table 1 gives an overview of the Gaussian fit parameters for frequency distributions of selected subsets of the GSs separated by season or by latitude regions. Included are the location of the maxima and the FWHM of the Gaussian fit as well as the correlation coefficient $R^{2}$ for the quality of the fit to the data. In general the results are variable because of the large differences in sample size. However, when only considering distributions with an $R^{2}$ larger than 0.95 (subsamples for summer, winter, northern midlatitudes, and tropics), the peak values fall in the range of -3.4 to $-4.9 \mathrm{ppb}$. This gives confidence in using a global offset of $-3.9 \mathrm{ppb}$ to combine TES and IASI average ozone mixing ratios in the chosen pressure range.

\subsection{Sampling considerations}

Between 2004 and 2011, the nominal mode of TES operation involved GSs with regular sampling over the globe. In 2011, the TES observing strategy shifted away from routine GS measurements in order to focus on special observations over select regions, to preserve the lifetime of the instrument. IASI-1, on MetOp-A, has been operational since 2007. IASI2, on MetOp-B, was launched in 2012. The IASI series will be continued with future missions, with IASI-3 on MetOp-
Table 1. Results for the Gaussian fit through the IASI-TES frequency distribution for different seasons and for different latitude bands. The latitude bands were separated by the polar circle and the Tropic of Cancer. Please note that TES measured only between $70^{\circ} \mathrm{N}$ and $50^{\circ} \mathrm{S}$ latitude.

\begin{tabular}{lrrrc}
\hline & $N$ & $\begin{array}{r}\text { Peak } \\
(\mathrm{ppb})\end{array}$ & $\begin{array}{r}\text { FWHM } \\
(\mathrm{ppb})\end{array}$ & $R^{2}$ \\
\hline Spring & 630 & $-1.7 \pm 0.3$ & 16.5 & 0.930 \\
Summer & 1450 & $-4.9 \pm 0.3$ & 19.1 & 0.954 \\
Autumn & 397 & $-4.1 \pm 0.4$ & 15.4 & 0.897 \\
Winter & 1443 & $-4.1 \pm 0.1$ & 16.4 & 0.968 \\
Northern high latitudes & 58 & $-7.0 \pm 0.3$ & 3.9 & 0.448 \\
Northern midlatitudes & 1567 & $-4.6 \pm 0.2$ & 24.7 & 0.953 \\
Tropics & 1714 & $-3.4 \pm 0.1$ & 14.7 & 0.983 \\
Southern midlatitudes & 581 & $-4.5 \pm 0.4$ & 17.2 & 0.904 \\
All & 3920 & $-3.9 \pm 0.2$ & 17.6 & 0.988 \\
\hline
\end{tabular}

C planned for 2017/18 and three IASI-NG (next generation) missions planned after that.

IASI data are not currently routinely processed through the TES algorithm, which was originally set up for relatively small TES-like, rather than IASI-like, data volumes. Therefore, for this work we choose to process a subset of IASI scenes over selected regions of interest (ROIs - shown in Fig. 4) for the construction of the combined time series. We evaluate the consistency of the TES and IASI-1 monthly mean column-average mixing ratios for these ROIs, using the overlap between datasets in the years 2008-2011.

Compared to IASI, the TES sampling is sparse. One approach to constructing the time series would be to restrict the data to collocated TES and IASI points for cases in which both are deemed to be sufficiently clear-sky. However, we find that this approach leads to an unacceptable reduction in the number of TES data points (see below). Therefore, we instead choose to subsample the IASI data over the ROIs without the requirement of co-location with TES points. The impact of the IASI subsampling is explored below.

IASI scenes with sample sizes ranging from 50 to 2000 were randomly selected within the eastern Asia ROI for May 2009. The resulting monthly mean ozone is presented in Fig. 5. The error bars are the $95 \%$ confidence limits (CL) for the mean $x_{\text {mean }}$, assuming a normal distribution calculated from

$\mathrm{CL}=x_{\text {mean }} \pm 1.96 \frac{\sigma}{\sqrt{N}}$,

with $\sigma$ being the sample standard deviation and $N$ the sample size. These confidence limits for the monthly mean are an approximation since ozone itself is neither temporally nor spatially uncorrelated in the atmosphere. The actual sample standard deviation of about $15 \mathrm{ppb}$ does not change with the sample size (not shown), and hence the confidence limits vary with the square root of the sample size only. This indicates that it is valid to assume a normal distribution for the 


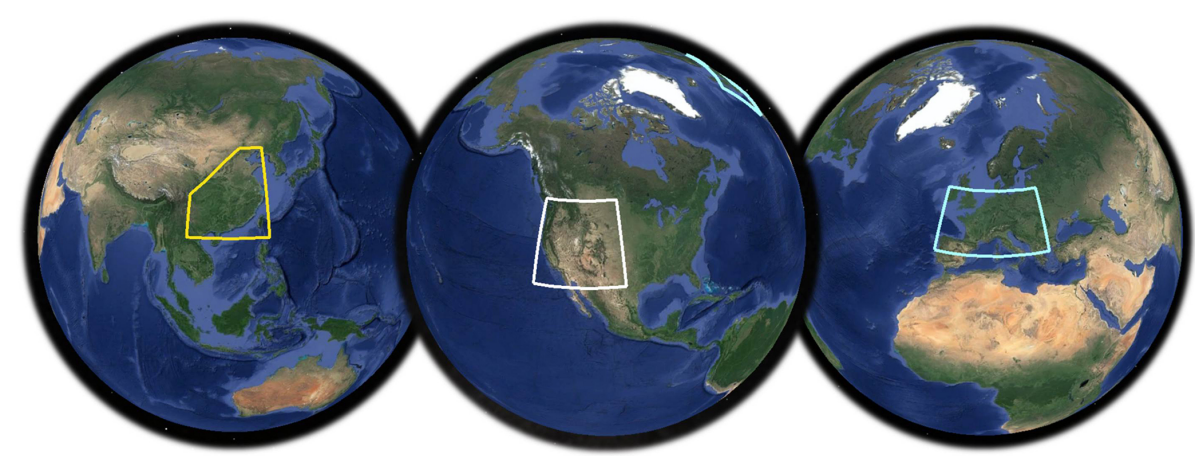

Figure 4. Regions of interest: eastern Asia (corner points: $41.5^{\circ} \mathrm{N}, 116^{\circ} \mathrm{E} ; 30^{\circ} \mathrm{N}, 102.5^{\circ} \mathrm{E} ; 20^{\circ} \mathrm{N}, 102.5^{\circ} \mathrm{E} ; 20^{\circ} \mathrm{N}, 123^{\circ} \mathrm{E} ; 41.5^{\circ} \mathrm{N}$, $116^{\circ} \mathrm{E}$ ), the western US (box between 30 and $50^{\circ} \mathrm{N}, 125$ and $100^{\circ} \mathrm{W}$ ), and Europe (box between 40 and $55^{\circ} \mathrm{N}, 10^{\circ} \mathrm{W}$ and $25^{\circ} \mathrm{E}$ ).

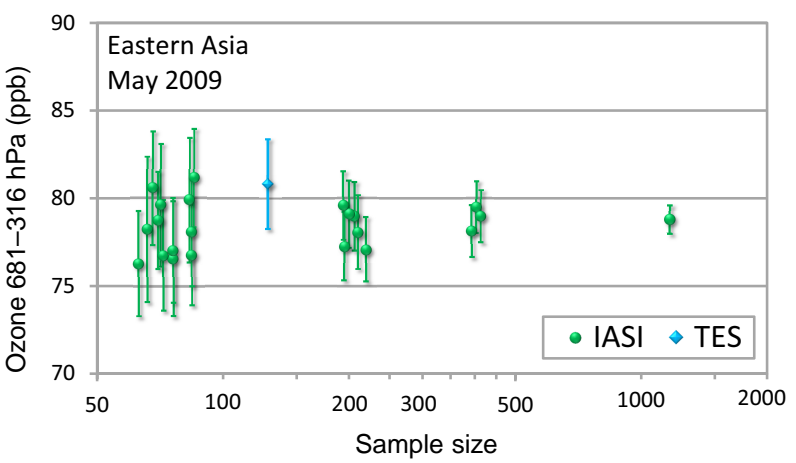

Figure 5. Monthly mean ozone for randomly selected IASI scenes within the eastern Asia ROI for May 2009. IASI-TOE data have been offset-corrected. A sample of 200 IASI scenes is deemed sufficient for an uncertainty of $1.9 \mathrm{ppb}$ or better for an area the size of the eastern Asia box.

ozone, at least for the given example. We conclude that a sample of 200 IASI scenes is sufficient for an uncertainty of $1.9 \mathrm{ppb}$ or better for an area of the size of the eastern Asia box. This is about $2-3 \%$ of the mean mixing ratio for the chosen ROIs and about $10 \%$ of the variation observed for the deseasonalised time series (see Sect. 4). The areas of the western US and Europe ROIs scale by a factor of 1.28 and 1.20 , respectively, and we aim to sample at least 250 scenes for those ROIs. In many cases, larger sample sizes have been used. This is due to the fact that a larger number than the number of target scenes is selected first, and then the actual throughput of successfully retrieved ozone profiles depends on the quality screening (see Fig. S3 in the Supplement for the sample sizes). On average for all the years in the time series below, the IASI limits of confidence are 1.9, 1.7, and $1.5 \mathrm{ppb}$ for the eastern Asia, western US, and Europe ROI, respectively. In the example shown in Fig. 5, the TES confidence limit is $2.3 \mathrm{ppb}$ for 128 scenes. In general, there are less TES scenes than IASI scenes and the average confidence limit for all ROIs for TES monthly mean ozone is $2.6 \mathrm{ppb}$. An

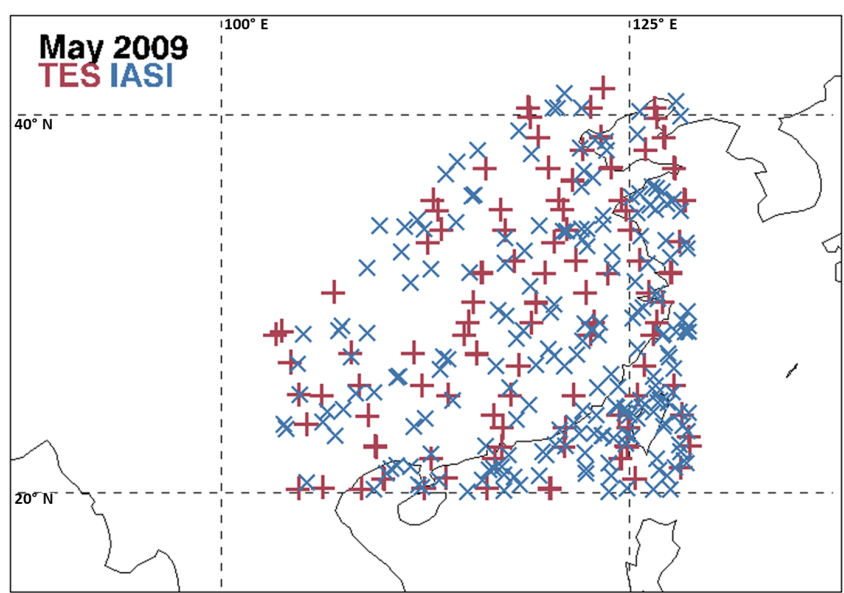

Figure 6. An example of the spatial distribution for 206 IASI and 128 TES data points.

example for the spatial distribution of the satellite scenes is presented in Fig. 6 for 206 IASI data points.

\section{Results}

Figure 7 shows the time series of partial column ozone for the three ROIs. In these figures, the IASI monthly means have been adjusted by a constant value of $+3.9 \mathrm{ppb}$ based on our analysis in Sect. 3.2. There is an overlap of about 3 years between TES and IASI for eastern Asia and the western US ROIs. Over Europe, the overlap is only $\sim 2$ years because the latitude range of the TES GSs was limited to $30^{\circ} \mathrm{S}-50^{\circ} \mathrm{N}$ from 2010 onward. In this part of the study, we relax the cloud screening thresholds to 2.0 for the TES average cloud optical depth and to $13 \%$ cloud fraction for IASI scenes which are more widely used thresholds (e.g. Clerbaux et al. 2009).

Data gaps in the time series occur for several reasons. A data point for a whole month is removed if an instrument has missing data for more than a week for that given month or if 

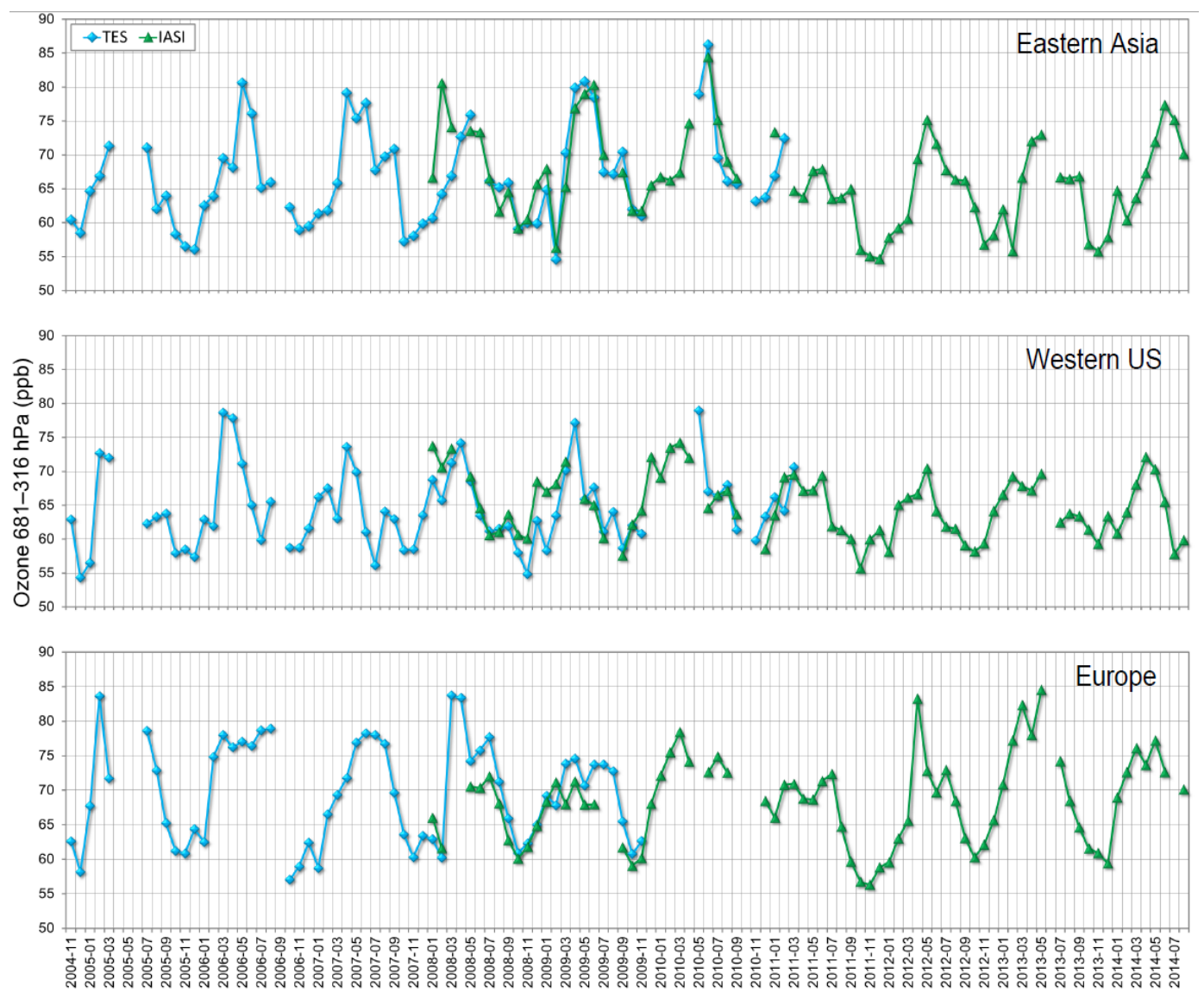

Figure 7. Time series of partial column-averaged ozone for the three ROIs. IASI-TOE monthly means have been adjusted by a constant value of $+3.9 \mathrm{ppb}$.

the whole area of the ROI is not completely covered by an instrument due to cloud cover or missing orbits. Missing orbits can lead to biased sampling of the random number generator within the ROI of a given month. However, the data have been screened for this by looking at the number of satellite scenes per day used for calculating the monthly mean: if the number of satellite scenes for 3 or more consecutive days is twice as high as the average for the rest of the month, the monthly data points are removed as well. For all data points included in the time series, care was taken to ensure that the initial distribution is unbiased.

TES and IASI agree well for the overlap period; differences are mostly within the range of less than $4.5 \mathrm{ppb}$ as expected from the calculated confidence limits (see Sect. 3.3). In particular, eastern Asia shows very good agreement between TES and IASI-TOE ozone for 2008-2011, giving confidence in the consistency of the time series. There are a few cases where IASI ozone exceeds TES ozone by more than the confidence limits of the monthly mean, e.g. February 2008 for eastern Asia or January 2009 for the western US ROI. These instances can be traced back to some localised enhanced ozone which was not detected by TES's coarser sampling and in these cases the required condition for randomness for using Eq. (1) is not fulfilled. The variation over the 10 years of data is dominated by the seasonal cycle.

Figure 8 shows the deseasonalised time series for the three ROIs, in order to better show the long-term variations in ozone for the 2004-2014 time period. We remove the seasonal variation by calculating the mean ozone over all of the years for each month and subtracting this mean from the respective months in the time series. For the years where TES and IASI overlap, the mean of the two data points is used. From November 2004 to May 2005, TES measured with a somewhat sparser sampling pattern than the period after May 2005 and consequently the error in the monthly mean is larger for this portion of the time series because there are fewer data points to average (see Fig. S3). This data was excluded from the calculation of the overall monthly mean used to deseasonalise the data.

As seen in Fig. 8, ozone over eastern Asia rose relatively steadily from 2004-2010 but dropped suddenly in 2011. This is also clearly apparent when looking only at the annual maxima in Fig. 7. While ozone has been somewhat increasing once again since 2011, a clear upward trend is not observed 

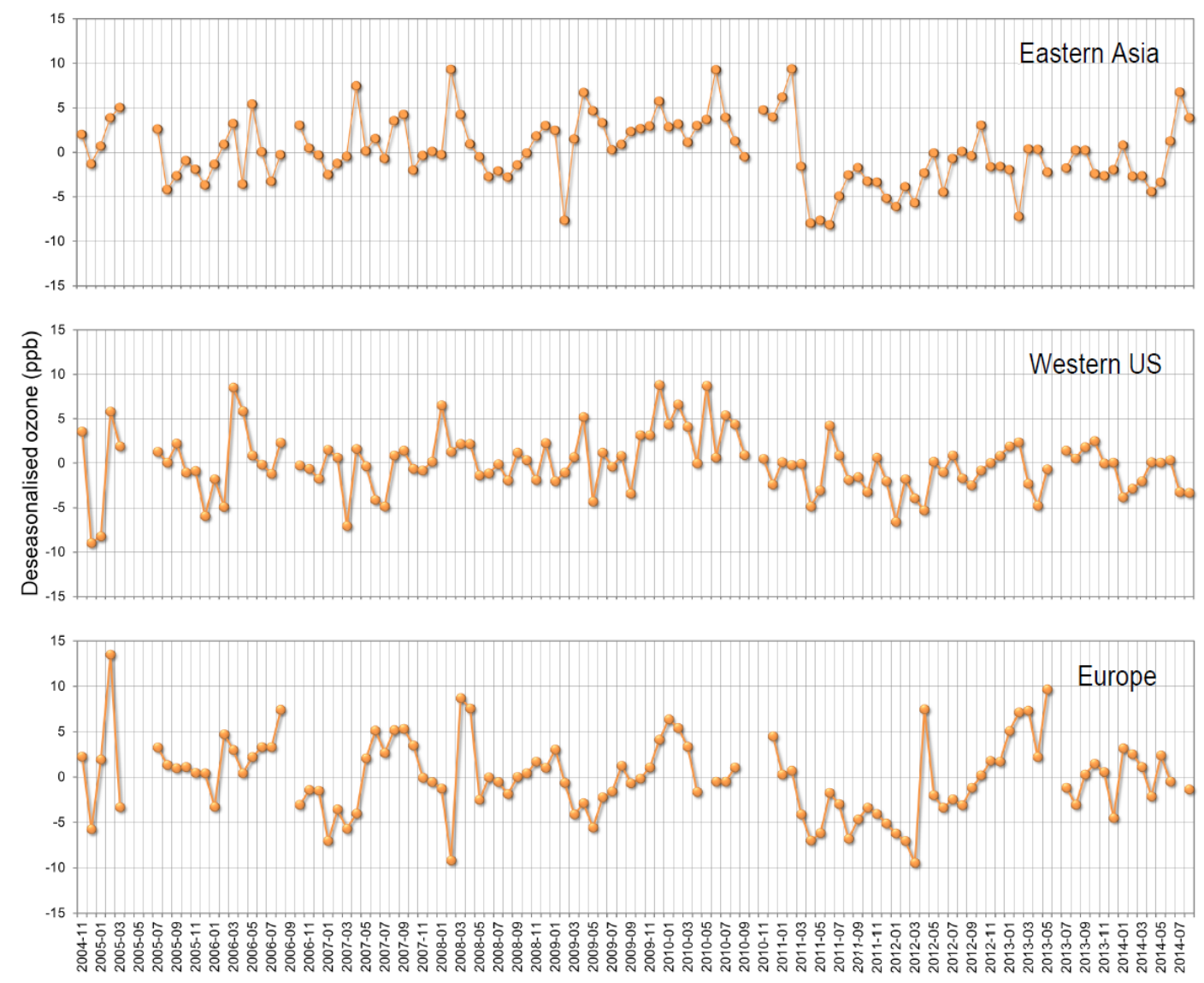

Figure 8. Deseasonalised joint time series for TES and IASI-TOE for the data from Fig. 7.

and ozone has also not yet reached pre-2011 values. This drop is significant within the confidence limits of $1.9 \mathrm{ppb}$ for IASI and $2.6 \mathrm{ppb}$ for TES for the monthly mean ozone for eastern Asia, despite a somewhat large standard deviation of $15 \mathrm{ppb}$ for both instruments. A similar sharp drop in 2011 can also be observed in ozone sonde data over Hilo, Hawaii (see Fig. 9), a location strongly influenced by outflow of freetropospheric air from Asia (Lin et al., 2014). The ozone mixing ratios measured by the sondes between 681 and $316 \mathrm{hPa}$, the same pressure range as for TES and IASI, have been averaged and then deseasonalised. We used the full dataset since 1991 to remove the seasonality, but we only show the same years as for the combined TES and IASI time series starting in 2004. For this time period, the mean standard deviation for the monthly mean ozone from the sondes is $9 \mathrm{ppb}$ and the confidence limits (see Eq. 1) are the same since sondes are launched about once per week. Note that we have not applied the satellite AKs to the sonde profiles and the ozone data in Fig. 9 are completely independent of the TES and IASI measurements. For any given region, long-term variations in free-tropospheric ozone can be affected by changes in local emissions of ozone precursors, changes in long-range transport within the troposphere, and downward transport from the stratosphere (see e.g. Lin et al., 2012, 2014). The com-

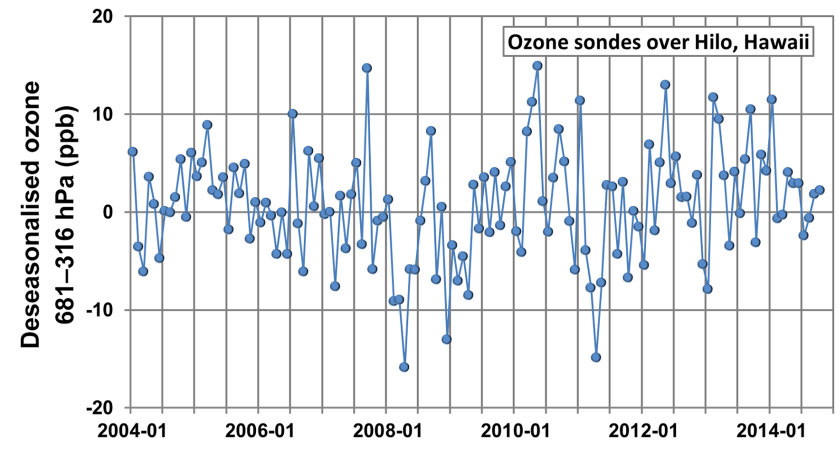

Figure 9. Deseasonalised time series of ozone measured by sondes in the pressure range of $681-316 \mathrm{hPa}$ over Hilo, Hawaii.

bined TES-IASI time series presented here have the potential to be used to aid the attribution of the relative contributions from these effects, although such a study is outside the scope of this paper.

In contrast to eastern Asia, ozone over the western US and Europe has remained relatively constant over the past decade. The time series for these regions are dominated by interannual variability, some of which is coherent in all three regions 
(for example, high ozone in spring 2008 and high ozone in 2010 followed by lower ozone in 2011).

\section{Summary and discussion}

We have assessed the consistency between time series of tropospheric ozone from TES and IASI-TOE retrievals, using a consistent retrieval algorithm applied to the radiances of both instruments. TES exhibits slightly better sensitivity than IASI, due to the finer spectral resolution of the TES instrument. Despite the small differences in sensitivity, the time series of the 681-316 hPa partial column-averaged ozone mixing ratios show good agreement for the years 2008-2011, after the removal of a constant $-3.9 \mathrm{ppb}$ offset from TES in the IASI-TOE record.

Combined TES and IASI monthly-mean time series were constructed for three regions of interest: eastern Asia, the western US, and Europe. Ozone has remained relatively constant over the western US and Europe over the past decade, and ozone changes in those regions are dominated by seasonal and interannual variability. The deseasonalised time series for eastern Asia, on the other hand, shows an overall increase between 2004 and 2010, with a drop in 2011 followed by a slow or no increase through 2014. Somewhat surprisingly, ozone over eastern Asia has not yet returned to pre2011 levels. To the best of our knowledge, only one study, by Chen et al. (2014), suggests that the rapid increase in ozone over Asia may have levelled-off in recent years. That study, however, focused on Taiwan and found that a change in the slope of the ozone trend from 1994 to 2012 occurred in 2007. The complex temporal changes in ozone over eastern Asia show that ozone changes driven by changing concentrations of precursor gases and other sources, such as stratospheretroposphere exchange, still need to be better understood in the context of long-term trends and prognoses. Understanding what drives changes in ozone over eastern Asia is particularly critical for air quality in the western US, since it has been speculated that transport of increasing ozone from Asia may contribute to non-attainment of EPA air quality standards in the future (e.g. Hudman et al., 2004).

\section{Data availability}

All data used in this study are archived at the Jet Propulsion Laboratory and are available from the authors upon request (vivienne.h.payne@jpl.nasa.gov).

The Supplement related to this article is available online at doi:10.5194/acp-16-10229-2016-supplement.
Acknowledgements. We acknowledge the NOAA/CLASS data centre for the IASI Level 1c spectra and EUMETSAT for the Level 2 data. IASI is a joint mission of EUMETSAT and the Centre National d'Études Spatiales (CNES, France). Part of the research was carried out at the Jet Propulsion Laboratory, California Institute of Technology, under a contract with the National Aeronautics and Space Administration. We acknowledge NASA support under the grant NNX11AE19G. The Hilo ozone sonde data were provided by the Global Monitoring Division of NOAA (www.esrl.noaa.gov/gmd).

Edited by: M. Van Roozendael

Reviewed by: two anonymous referees

\section{References}

Beig, G. and Singh, V.: Trends in tropical tropospheric column ozone from satellite data and MOZART model, Geophys. Res. Lett., 34, L17801, doi:10.1029/2007GL030460, 2007.

Bey, I., Jacob D., J., Yantosca, R. M., Logan, J. A., Field, B., Fiore, A. M., Li, Q., Liu, H., Mickley, L. J., and Schultz, M.: Global modeling of tropospheric chemistry with assimilated meteorology: Model description and evaluation, J. Geophys. Res., 106, 23073-23096, 2001.

Bowman, K. and Henze, D. K.: Attribution of direct ozone radiative forcing to spatially resolved emissions, Geophys. Res. Lett, 39, L22704, doi:10.1029/2012GL053274, 2012.

Bowman, K. W., Worden, J., Steck, T., Worden, H. M., Clough, S., and Rodgers, C.: Capturing time and vertical variability of tropospheric ozone: A study using TES nadir retrievals, J. Geophys. Res, 107, 4723, doi:10.1029/2002JD002150, 2002.

Bowman, K. W., Rodgers, C. D., Kulawik, S. S., Worden, J., Sarkissian, E., Osterman, G., Steck, T., Lou, M., Eldering, A., Shephard, M., Worden, H., Lampel, M., Clough, S., Brown, P., Rinsland, C., Gunson, M., and Beer, R.: Tropospheric emission spectrometer: Retrieval method and error analysis, IEEE T. Geosci. Remote, 44, 1297-1307, doi:10.1109/tgrs.2006.871234, 2006.

Boxe, C. S., Worden, J. R., Bowman, K. W., Kulawik, S. S., Neu, J. L., Ford, W. C., Osterman, G. B., Herman, R. L., Eldering, A., Tarasick, D. W., Thompson, A. M., Doughty, D. C., Hoffmann, M. R., and Oltmans, S. J.: Validation of northern latitude Tropospheric Emission Spectrometer stare ozone profiles with ARC-IONS sondes during ARCTAS: sensitivity, bias and error analysis, Atmos. Chem. Phys., 10, 9901-9914, doi:10.5194/acp10-9901-2010, 2010.

Chen, S.-P., Chang, C.-C., Liu, J.-J., Chou, C. C.-K., Chang, J. S., and Wang, J.-L.: Recent improvement in air quality as evidenced by the island-wide monitoring network in Taiwan, Atmos. Environ., 96, 70-77, doi:10.1016/j.atmosenv.2014.06.060, 2014.

Clerbaux, C., Boynard, A., Clarisse, L., George, M., Hadji-Lazaro, J., Herbin, H., Hurtmans, D., Pommier, M., Razavi, A., Turquety, S., Wespes, C., and Coheur, P.-F.: Monitoring of atmospheric composition using the thermal infrared IASI/MetOp sounder, Atmos. Chem. Phys., 9, 6041-6054, doi:10.5194/acp-9-6041-2009, 2009.

Cooper, O. R., Parrish, D. D., Stohl, A., Trainer, M., Nedelec, P., Thouret, V., Cammas, J. P., Oltmans, S. J., Johnson, B. J., Tara- 
sick, D., Leblanc, T., McDermid, I. S., Jaffe, D., Gao, R., Stith, J., Ryerson, T., Aikin, K., Campos, T., Weinheimer, A., and Avery, M. A.: Increasing springtime ozone mixing ratios in the free troposphere over western North America, Nature, 463, 344-348, doi:10.1038/nature08708, 2010.

Cooper, O. R., Parrish, D. D., Ziemke, J., Balashov, N. V., Cupeiro, M., Galbally, I. E., Gilge, S., Horowitz, L., Jensen, N. R., Lamarque, J.-F., Naik, V., Oltmans, S. J., Schwab, J., Shindell, D. T., Thompson, A. M., Thouret, V., Wang, Y., and Zbinden, R. M.: Global distribution and trends of tropospheric ozone: An observation-based review, Elem. Sci. Anth., 2, 000029, doi:10.12952/journal.elementa.000029, 2014.

De Smedt, I., Stavrakou, T., Müller, J.-F., van der A, R. J., and Van Roozendael, M.: Trend detection in satellite observations of formaldehyde tropospheric columns, Geophys. Res. Lett., 37, L18808, doi:10.1029/2010GL044245, 2009.

Dufour, G., Eremenko, M., Orphal, J., and Flaud, J.-M.: IASI observations of seasonal and day-to-day variations of tropospheric ozone over three highly populated areas of China: Beijing, Shanghai, and Hong Kong, Atmos. Chem. Phys., 10, 37873801, doi:10.5194/acp-10-3787-2010, 2010.

Eastham, S. D., Weisenstein, D. K., and Barrett, S. R. H.: Development and evaluation of the unified tropospheric-stratospheric chemistry extension (UCX) for the global chemistry-transport model GEOS-Chem, Atmos. Environ., 89, 52-63, 2014.

Ebojie, F., Burrows, J. P., Gebhardt, C., Ladstätter-Weißenmayer, A., von Savigny, C., Rozanov, A., Weber, M., and Bovensmann, H.: Global tropospheric ozone variations from 2003 to 2011 as seen by SCIAMACHY, Atmos. Chem. Phys., 16, 417-436, doi:10.5194/acp-16-417-2016, 2016.

Fiore, A. M., Dentener, F. J., Wild, O., Cuvelier, C., Schultz, M. G., Hess, P., Textor, C., Schulz, M., Doherty, R. M., Horowitz, L. W., MacKenzie, I. A., Sanderson, M. G., Shindell, D. T., Stevenson, D. S., Szopa, S., van Dingenen, R., Zeng, G., Atherton, C., Bergmann, D., Bey, I., Carmichael, G., Collins, W. J., Duncan, B. N., Faluvegi, G., Folberth, G., Gauss, M., Gong, S., Hauglustaine, D., Holloway, T., Isaksen, I. S. A., Jacob, D. J., Jonson, J. E., Kaminski, J. W., Keating, T. J., Lupu, A., Marmer, E., Montanaro, V., Park, R. J., Pitari, G., Pringle, K. J., Pyle, J. A., Schroeder, S., Vivanco, M. G., Wind, P., Wojcik, G., Wu, S., and Zuber, A.: Multimodel estimates of intercontinental sourcereceptor relationships for ozone pollution, J. Geophys. Res, 114, D04301, doi:10.1029/2008JD010816, 2009.

Fry, M. M., Schwarzkopf, M. D., Adelman, Z., Naik, V., Collins, W. J., and West, J. J.: Net radiative forcing and air quality responses to regional $\mathrm{CO}$ emission reductions, Atmos. Chem. Phys., 13, 5381-5399, doi:10.5194/acp-13-5381-2013, 2013.

Fry, M. M., Schwarzkopf, M. D., Adelman, Z., and West, J. J.: Air quality and radiative forcing impacts of anthropogenic volatile organic compound emissions from ten world regions, Atmos. Chem. Phys., 14, 523-535, doi:10.5194/acp-14-523-2014, 2014.

Gauss, M., Myhre, G., Pitari, G., Prather, M. J., Isaksen, I. S. A., Berntsen, T. K., Brasseur, G. P., Dentener, F. J., Derwent, R. G., Hauglustaine, D. A., Horowitz, L. W., Jacob, D. J., Johnson, M., Law, K. S., Mickley, L. J., Muller, J.-F., Plantevin, P.-H., Pyle, J. A., Rogers, H. L., Stevenson, D. S., Sundet, J. K., van Weele, M., and Wild, O.: Radiative forcing in the 21 st century due to ozone changes in the troposphere and the lower stratosphere, J. Geophys. Res., 108, 4292, doi:10.1029/2002JD002624, 2003.
Hilboll, A., Richter, A., and Burrows, J. P.: Long-term changes of tropospheric $\mathrm{NO}_{2}$ over megacities derived from multiple satellite instruments, Atmos. Chem. Phys., 13, 4145-4169, doi:10.5194/acp-13-4145-2013, 2013.

Hudman, R. C., Jacob, D. J., Cooper, O. R., Evans, M. J., Heald, C. L., Park, R. J., Fehsenfeld, F., Flocke, F., Holloway, J., Hübler, G., Kita, K., Koike, M., Kondo, Y., Neuman, A., Nowak, J., Oltmans, S., Parrish, D., Roberts, J. M., and Ryerson, T.: Ozone production in transpacific Asian pollution plumes and implications for ozone air quality in California, J. Geophys. Res., 109, D23S10, doi:10.1029/2004JD004974, 2004.

Jacob, D. J., Logan, J. A., and Murti, P. P.: Effect of rising Asian emissions on surface ozone in the United States, J. Geophys. Res., 26, 2175-2178, 1999.

Jaffe, D. and Ray, J.: Increase in surface ozone at rural sites in the western US, Atmos. Environ., 41, 5452-5463, doi:10.1016/j.atmosenv.2007.02.034, 2007.

Jiang, Z., Worden, J. R., Jones, D. B. A., Lin, J.-T., Verstraeten, W. W., and Henze, D. K.: Constraints on Asian ozone using Aura TES, OMI and Terra MOPITT, Atmos. Chem. Phys., 15, 99-112, doi:10.5194/acp-15-99-2015, 2015.

Kulawik, S. S., Worden, J., Eldering, A., Bowman, K., Gunson, M., Osterman, G. B., Zhang, L., Clough, S. A., Shephard, M. W., and Beer, R.: Implementation of cloud retrievals for Tropospheric Emission Spectrometer (TES) atmospheric retrievals: part 1. Description and characterization of errors on trace gas retrievals, J. Geophys. Res, 111, D24204, doi:10.1029/2005JD006733, 2006.

Lee, Y. C., Shindell, D. T., Faluvegi, G., Wenig, M., Lam, Y. F., Ning, Z., Hao, S., and Lai, C. S.: Increase of ozone concentrations, its temperature sensitivity and the precursor factor in South China, Tellus B, 66, 23455, doi:10.3402/tellusb.v66.23455, 2014.

Lin, M., Fiore, A. M., Horowitz, L. W., Cooper, O. R., Naik, V., Holloway, J., Johnson, B. J., Middlebrook, A. M., Oltmans, S. J., Pollack, I. B., Ryerson, T. B., Warner, J. X., Wiedinmyer, C., Wilson, J., and Wyman, B.: Transport of Asian ozone pollution into surface air over the western United States in spring, J. Geophys. Res, 117, D00V07, doi:10.1029/2011JD016961, 2012.

Lin, M., Horowitz, L.W., Oltmans, S. J., Fiore, A. M., and Fan, S.: Tropospheric ozone trends at Mauna Loa Observatory tied to decadal climate variability, Nat. Geosci. 7, 136-143, 2014.

Neu, J. L., Flury, T., Manney, G. L., Santee, M. L., Livesey, N. J., and Worden, J.: Tropospheric ozone variations governed by changes in stratospheric circulation, Nat. Geosci., 7, 340-344, doi:10.1038/ngeo2138, 2014.

Oetjen, H., Payne, V. H., Kulawik, S. S., Eldering, A., Worden, J., Edwards, D. P., Francis, G. L., Worden, H. M., Clerbaux, C., Hadji-Lazaro, J., and Hurtmans, D.: Extending the satellite data record of tropospheric ozone profiles from Aura-TES to MetOp-IASI: characterisation of optimal estimation retrievals, Atmos. Meas. Tech., 7, 4223-4236, doi:10.5194/amt-7-42232014, 2014.

Parrish, D. D., Millet, D. B., and Goldstein, A. H.: Increasing ozone in marine boundary layer inflow at the west coasts of North America and Europe, Atmos. Chem. Phys., 9, 1303-1323, doi:10.5194/acp-9-1303-2009, 2009.

Reidmiller, D. R., Fiore, A. M., Jaffe, D. A., Bergmann, D., Cuvelier, C., Dentener, F. J., Duncan, B. N., Folberth, G., Gauss, M., Gong, S., Hess, P., Jonson, J. E., Keating, T., Lupu, A., 
Marmer, E., Park, R., Schultz, M. G., Shindell, D. T., Szopa, S., Vivanco, M. G., Wild, O., and Zuber, A.: The influence of foreign vs. North American emissions on surface ozone in the US, Atmos. Chem. Phys., 9, 5027-5042, doi:10.5194/acp-9-5027-2009, 2009.

Safieddine, S., Clerbaux, C., George, M., Hadji-Lazaro, J., Hurtmans, D., Coheur, P.-F., Wespes, C., Loyola, D., Valks, P., and Hao, N.: Tropospheric ozone and nitrogen dioxide measurements in urban and rural regions as seen by IASI and GOME-2, J. Geophys. Res.-Atmos., 118, 10555-10566, doi:10.1002/jgrd.50669, 2013.

Singh, H. B., Brune, W. H., Crawford, J. H., Flocke, F., and Jacob, D. J.: Chemistry and transport of pollution over the Gulf of Mexico and the Pacific: spring 2006 INTEX-B campaign overview and first results, Atmos. Chem. Phys., 9, 2301-2318, doi:10.5194/acp-9-2301-2009, 2009.

Stevenson, D., Dentener, F. J., Schultz, M. G., Ellingsen, K., van Noije, T. P. C., Wild, O., Zeng, G., Amann, M., Atherton, C. S., Bell, N., Bergmann, D. J., Bey, I., Butler, T., Cofala, J., Collins, W. J., Derwent, R. G., Doherty, R., Drevet, J., Eskes, H. J., Fiore, A. M., Gauss, M., Hauglustaine, D. A., Horowitz, L. W., Isaksen, I. S. A., Krol, M. C., Lamarque, J. F., Lawrence, M. G., Montanaro, V., Muller, J. F., Pitari, G., Prather, M. J., Pyle, J. A., Rast, S., Rodriguez, J. M., Sanderson, M. G., Savage, N. H., Shindell, D. T., Strahan, S. E., Sudo, K., and Szopa, S.: Multi-model ensemble simulations of present-day and nearfuture tropospheric ozone, J. Geophys. Res., 111, D08301, doi:10.1029/2005JD006338, 2006.

Tanimoto, H., Ohara, T., and Uno, I.: Asian anthropogenic emissions and decadal trends in springtime tropospheric ozone over Japan: 1998-2007, Geophys. Res. Lett., 36, L23802, doi:10.1029/2009GL041382, 2009.

van der A, R. J., Eskes, H. J., Boersma, K. F., van Noije, T. P. C., Van Roozendael, M., De Smedt, I., Peters, D. H. M. U., and Meijer, E. W.: Trends, seasonal variability and dominant $\mathrm{NO}_{x}$ source derived from a ten year record of $\mathrm{NO}_{2}$ measured from space, $\mathrm{J}$. Geophys. Res., 113, D04302, doi:10.1029/2007JD009021, 2008.

Verstraeten, W. W., Boersma, K. F., Zörner, J., Allaart, M. A. F., Bowman, K. W., and Worden, J. R.: Validation of six years of TES tropospheric ozone retrievals with ozonesonde measurements: implications for spatial patterns and temporal stability in the bias, Atmos. Meas. Tech., 6, 1413-1423, doi:10.5194/amt-61413-2013, 2013.

Verstraeten, W. W., Neu, J. L., Williams, J. E., Bowman, K. W., Worden, J. R., and Boersma, K. F.: Rapid increases in tropospheric ozone production and export from China, Nat. Geosci, 8, 690-695, doi:10.1038/ngeo2493, 2015.

Wang, Y., Konopka, P., Liu, Y., Chen, H., Müller, R., Plöger, F., Riese, M., Cai, Z., and Lü, D.: Tropospheric ozone trend over Beijing from 2002-2010: ozonesonde measurements and modeling analysis, Atmos. Chem. Phys., 12, 8389-8399, doi:10.5194/acp-12-8389-2012, 2012.
Wild, O. and Akimoto, H.: Intercontinental transport of ozone and its precursors in a three-dimensional global CTM, J. Geophys. Res, 106, 27729-27744, 2001.

Worden, H. M., Bowman, K. W., Worden, J. R., Eldering, A., and Beer, R.: Satellite measurements of the clear-sky greenhouse effect from tropospheric ozone, Nat. Geosci., 1, 305-308, doi:10.1038/ngeo182, 2008.

Worden, H. M., Deeter, M. N., Frankenberg, C., George, M., Nichitiu, F., Worden, J., Aben, I., Bowman, K. W., Clerbaux, C., Coheur, P. F., de Laat, A. T. J., Detweiler, R., Drummond, J. R., Edwards, D. P., Gille, J. C., Hurtmans, D., Luo, M., MartínezAlonso, S., Massie, S., Pfister, G., and Warner, J. X.: Decadal record of satellite carbon monoxide observations, Atmos. Chem. Phys., 13, 837-850, doi:10.5194/acp-13-837-2013, 2013.

Worden, J., Jones, D. B. A., Liu, J., Parrington, M., Bowman, K., Stajner, I., Beer, R., Jiang, J., Thouret, V., Kulawik, S., Li, J.-L. F., Verma, S., and Worden, H.: Observed vertical distribution of tropospheric ozone during the Asian summertime monsoon, J. Geophys. Res, 114, D13304, doi:10.1029/2008JD010560, 2009.

Young, P. J., Archibald, A. T., Bowman, K. W., Lamarque, J.-F., Naik, V., Stevenson, D. S., Tilmes, S., Voulgarakis, A., Wild, O., Bergmann, D., Cameron-Smith, P., Cionni, I., Collins, W. J., Dalsøren, S. B., Doherty, R. M., Eyring, V., Faluvegi, G., Horowitz, L. W., Josse, B., Lee, Y. H., MacKenzie, I. A., Nagashima, T., Plummer, D. A., Righi, M., Rumbold, S. T., Skeie, R. B., Shindell, D. T., Strode, S. A., Sudo, K., Szopa, S., and Zeng, G.: Preindustrial to end 21st century projections of tropospheric ozone from the Atmospheric Chemistry and Climate Model Intercomparison Project (ACCMIP), Atmos. Chem. Phys., 13, 20632090, doi:10.5194/acp-13-2063-2013, 2013.

Zhang, L., Jacob, D. J., Boersma, K. F., Jaffe, D. A., Olson, J. R., Bowman, K. W., Worden, J. R., Thompson, A. M., Avery, M. A., Cohen, R. C., Dibb, J. E., Flock, F. M., Fuelberg, H. E., Huey, L. G., McMillan, W. W., Singh, H. B., and Weinheimer, A. J.: Transpacific transport of ozone pollution and the effect of recent Asian emission increases on air quality in North America: an integrated analysis using satellite, aircraft, ozonesonde, and surface observations, Atmos. Chem. Phys., 8, 6117-6136, doi:10.5194/acp-8-6117-2008, 2008.

Zhang, Q., Streets, D. G., Carmichael, G. R., He, K. B., Huo, H., Kannari, A., Klimont, Z., Park, I. S., Reddy, S., Fu, J. S., Chen, D., Duan, L., Lei, Y., Wang, L. T., and Yao, Z. L.: Asian emissions in 2006 for the NASA INTEX-B mission, Atmos. Chem. Phys., 9, 5131-5153, doi:10.5194/acp-9-5131-2009, 2009.

Zhou, D. K., Larar, A. M., Liu, X., Smith, W. L., Strow, L. L., Yang, P., Schlüssel, P., and Calbet, X.: Global Land Surface Emissivity Retrieved From Satellite Ultraspectral IR Measurements, IEEE T. Geosci. Remote, 49, 1277-1290, doi:10.1109/tgrs.2010.2051036, 2011. 